\title{
Effectiveness of Learning during the Corona Pandemic
}

\author{
Parijem $^{1}$, Wakhudin ${ }^{2}$, Subiarto $^{3}$

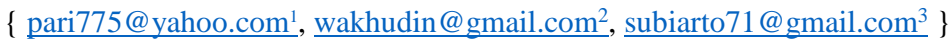 \\ 1,2,3 Master of Basic Education, Universitas Muhammadiyah Purwokerto, \\ JL. KH Ahmad Dahlan,Banyumas 53182, Indonesia
}

\begin{abstract}
This research was conducted on the basis of the author's concerns during the Corona Pandemic, especially the situation in the education sector. As an actor of education, thewriter feels compelled to contribute thoughts that might be useful for education in the future. The purpose of this study was to determine the effectiveness of learning during the Corona pandemic. The research method apart from distributing questionnaires, the author also conducts documentation studies and observations in the field. The results of this study are to state that the effectiveness of learning during the Corona pandemic is currently not effective, there are still many teachers who are confused about learning during the corona pandemic. This confusion is not only due to the limited means for online learning, as well as the inadequacy of human resources to face a completely unexpected and unexpected situation so that there is no preparation at all to face the Corona pandemic. The conclusion in this study is that the effectiveness of learning during the corona pandemic has not been achieved. This is due to several factors, including: the government is not ready to provide facilities and infrastructure for online learning in all schools in Indonesia, the ability or competence of teachers who are also not ready for online learning, and uneven networks in rural schools.
\end{abstract}

Keywords: Effectiveness, Learning, Corona Pandemic

\section{Introduction}

The world of education is inevitably stumped by the Corona Pandemic. Teaching and learning activities as the spirit of the core activities at school are disrupted. There are no more teachers and students meeting to learn and interact with each other. The situation has forced schools to close the gates during the Corona pandemic. All students are forced to be able to study in their own homes. Limiting mass gatherings can reduce the potential for the spread of Covid-19. As an effort to prevent the spread of Covid-19, WHO recommends temporarily stopping activities that have the potential to cause crowds [1]. For this reason, conventional learning that gathers many students in one room needs to be reviewed for its implementation. Learning must be carried out with scenarios that are able to minimize physical contact between students and other students, or between students and teachers. The government's recommendation to stay at home and physical and social distancing must be followed by a change in the face-to-face learning model to online.

Face-to-face activities are learning activities in the form of a process of interaction between students, learning materials, teachers, and the environment. Face-to-face learning is a set of actions designed to support the learning process of students face-to-face directly, by taking into account external events that play a role in a series of external events that take place in students that can be 
known or predicted during the face-to-face process [2]. Face-to-face activities are learning activities in the form of a process of interaction between students and educators as well as with the surrounding environment. Learning interactions are in the classroom. Face-to-face learning has various advantages over both teachers and students, including: (1) formal discipline applied to face-to-face learning can form mental discipline; (2) facilitate immediate reinforcement; (3) facilitate the assessment process by the teacher; and (4) become a vehicle for learning to interact with students. Another advantage is the ability to socialize between lecturers / tutors and students, as well as among friends. Not only that, the teacher can directly observe the attitudes and behavior of students in receiving the material [3].

Online learning is learning that uses an internet network with accessibility, connectivity, flexibility, and the ability to generate various types of learning interactions [4]. Of course, not all teachers and students are ready for the transition to this learning model. There are still manyteachers and students who are unfamiliar with online learning. So far, they have been accustomed to teaching and learning face-to-face. No wonder, during the Corona pandemic, learning seemed less mature in preparation and even seemed to just give assignments. This is very far from the hopes and goals of the learning itself.

Learning takes place through our five sense organs [5]. Firstly, vision or visual, is seeing the occurrence of an event. Secondly, hearing or auditory, is hearing something sound. Thirdly, olfactory, is the smell of food makes us feel hungry. Forthly, taste, is the tongue feels and can distinguish between salty and sour. Lastly, touch or tactile, is feels touch and can distinguish between smooth and rough surfaces

In the learning process, it does not only involve mastering facts or concepts in a scientific field, but also involves feelings related to emotions, affection, hate, jealousy and spiritual desires [6]. So, all of course that in online learning must be adjusted by the teacher. And this is a tough task for teachers to be able to present quality and effective learning in achieving learning objectives. Learning objectives or also known as instructional objectives are basically formulations of behavior that students will have after carrying out the learning process or after participating in the learning process [7].

Learning activities at home are currently experienced by all students both in cities and in villages [8]. Online or online learning models are the mainstay of today. For schools in cities, this is not a problem because human resources and facilities are there. It is different again for schools in remote villages or mountains, this situation becomes a heavy burden for both teachers and students. How do you want online learning if many students and parents are not familiar with internet access. So far, what is being carried out is conventional system learning. This conventional system, in a situation during a pandemic, is certainly impossible to implement. This is certainly something that surprises and makes it difficult for both students, teachers, parents of students and also the community.

This is a big homework for the world of education, how can we compete with foreign countries if we still stutter online learning [7]. Whereas in the 21st century, mastery of technology is something that absolutely must be mastered. In the current situation, where online learning is very much needed, but apparently not all of them can implement it is very concerning. There are times when students and parents get confused when they are asked to open assignments online. Never mind classrooms, let alone learning through zooming, just for the sake of it, not all have it.

There must consideration for the government so that the fulfillment of IT facilities, facilities 
and infrastructure in educational institutions can bereached by all [7]. The procurement of laptops, tablets and internet networks needs to be more evenly distributed, because so far not all schools have obtained them. In the future, the abilityof teachers to manage IT-based and online learning is also a necessity. We have to admit that not all teachers are currently able to carry out online learning. This certainly raises a big question in our minds, Is learning effective during this Corona Pandemic?

Effectiveness is an activity that is carried out and has the impact and results as expected [. The criteria for effectiveness in learning include curriculum, absorption, the presence of teachers and students, and learning achievement [9]. Several studies have been conducted regarding the implementation of learning during the pandemic. These studies include research conducted by Khasanah et al, that the readiness of students in mastering technology to welcome tuweb activities is sure to run well [10].

Constraints regarding the network due to being influenced by areas with poor signal and weather such as heavy rain, blackouts, and others are currently being resolved with the WAG presence function which was previously made based on policy recommendations from Universitas Terbuka [10]. In addition, research conducted by Pujilestari have concluded is that the rapid development of information technology, especially the internet, opens up opportunities for the development of better information services in educational institutions [4].

After the outbreak of the COVID-19 pandemic to Indonesia in mid-March 2020, the local government issued a policy in the world of education, namely temporarily eliminating face-to-face learning and replaced with online learning, both at the primary and secondary school level, as well as at the college level [10]. This is manifested in a system called an electronic university (eUniversity). Another study conducted by Firman and Sari Rahayu Rahman stated that: (1) students already have the basic facilities needed to take part in online learning; (2) online learning has flexibility in its implementation and is able to encourage independent learning and motivation to be more active in learning; and (3) distance learning encourages the emergence of social distancing behavior and minimizes the appearance of student crowds so that it is considered to reduce the potential for the spread of Covid-19 in the campus environment [8].

\section{Method}

The research design were used is survey method. The respondents were elementary school teachers and principals in the Pejawaran District area, consisting of 29 teachers $(80.6 \%)$ and 7 principals (19.4\%). Questionnaires were distributed through the Whatsapp Group of UPT Dindikpora Pejawaran Group and the Elementary School Teachers Group. Then, the research data has been collected is analyzed qualitatively. The analysis is carried out every time the data is collected in the field on an ongoing basis. Data analysis techniques in this study are data collection, data reduction, data display, and drawing conclusions.

Data collection was carried out through observation, questionnaires, and documentation. Observations were made on phenomena related to teacher activities in learning during the Corona pandemic period. Questionnaires were conducted regarding the views and opinions of teachers in implementing the learning policy at home during the Corona pandemic. While the documentation in this study is used to determine the development of covid 19, and the effectiveness of the implementation of learning during the corona pandemic. Documents collected include: research results and also articles about learning during the pandemic, the results of deliberations or discussions with teachers relating to learning at home, student work results collected while studying 
at home during the corona pandemic.

In this study the data or information obtained from field notes were then summarized and focused on important things. In addition, the results of the questionnaire that were filled in by the respondents were also analyzed one by one. Data reduction were used to transforming raw data that arise from observations, questionnaires and documentation. The data that has been reduced are then displayed or presented in a systematic description in accordance with the objectives of this study. Data presentation includes the number and percentage of answers to each item in the questionnaire. The presentation of this data aims to make the data that has been collected and reduced can be communicated easily so that it can be understood.

\section{Research Result}

3.1. Teacher Responses to Home Learning Policies

Respondents stated that during the pandemic all schools implemented learning at home. It turns out that not all schools are able to carry out online learning. From the data, it is obtained that the types of learning at home used online or online are $52.8 \%$, semi-online $41.7 \%$, and the rest is offline learning. The implementation of learning at home also has not all been well scheduled, this can be seen from the answers of respondents who stated that the implementation of learning activities at home with only $72.2 \%$ scheduled and the rest is unscheduled.

3.2. Facilities and infrastructure for Implementing Home Learning Policies

From the results of the questionnaire, it was found that the devices or tools used were mostly handphones. From 35 respondents, there were $88.9 \%$ used handphone as a tool in the implementation of learning, and the rest use tablets and laptops. Most of them (88.6\%) have used internet from the their handphone, and the rest are using school wifi / wifi in public spaces and subscribed internet networks at home.

3.3. Material Preparation and Learning Implementation at home

More than a half respondents $(52.8 \%)$ have prepared of e-learning materials and lesson plans, and the rest $(47.2 \%)$ unprepared. This can also be seen from the teachers at the author's workplace who still rarely handed out lesson plans to be signed. The application or platform used in learning at home with an online system is still quite simple, namely using WA $91.2 \%$, the rest uses the Ministry of Education and Culture's study room 6.1\%, and 3\% uses other tasks.

The media used by teachers in learning at home learning policies include text, audio, visual, audio visual and a combination of text, audio, audio visual. In the use of this media, one teacher can choose more than one media, so the results obtained using text media (47.26\%), Audio $(13.9 \%)$, visual (8.6\%), audio visual (8.3\%), and a combination of text, audio, and visual $(50 \%)$.

The material used in learning activities at home is mostly homemade material. There were $88.6 \%$ teachers make it, and the rest from of community products (11.4). In this case, one teacher can use material from various methods. The method that dominates the learning activities at home is the assignment method (97.2\%), lectures (8.3\%), questions and answers (41.7\%), brainstorming (8.3\%). \%), trial $3(8.3 \%)$, and joint discussion $(8.3 \%)$. The evaluations used in implementing the home study policy mostly use written assessments, both offline and online. 
3.4. Teachers' responses to the Implementation of the Home Study Policy

There only $11.1 \%$ respondents have a good responses about the implementation of policies at home using online or online learning. The others is, $44.4 \%$ argued it was quite good, $36.1 \%$ stated it was not good enough, and the rest $8.3 \%$ argued it was not good. There is none of them said it was very good.

3.5. Teachers' Responses about Constraints faced in implementing the home learning program Based on the questionnaire answered by the respondents, there were several

Thre are problems in the implementation of online learning during the Corona pandemic. Firstly, $61.1 \%$ respondents have problem of internet networks or inadequate signals became. Then, more than half of student have not handphone that can access the internet. Besides, there are low ability of students and parents to operate their devices for internet access, the ability of parents to accompany children to learn online at home is still low, and the low interest of children learning online.

\section{Discussion}

This research data shows that there are still some teachers who have difficulty implementing online learning. The difficulties experienced include the preparation of materials, in the process of implementing and distributing tasks, and in evaluating them. This isexacerbated by the weakness of the existing internet network and the limitations of students / communities in accessing the internet. This can be seen from the respondent's input about the obstacles faced in the implementation of the home study program [3-4].

Although online learning fosters learning independence, for elementary school students this is very limited, because if they only read material and do assignments it will be difficult, they need direct verbal explanation and also guidance from the teacher regarding some complex material [4]. Communication with the teacher through the instant message application or in the discussion column provided by the virtual classroom application is not able to provide a comprehensive explanation of the material being discussed. The situation mentioned above resulted in the ineffectiveness of learning during the Covid 19 pandemic or the corona pandemic. The ineffectiveness of learning during the corona pandemic was also reflected in a questionnaire questionnaire aimed specifically at teachers at the author's place of work [8-10].

Based on respondents' input and also documentation and observation / observation studies, there are a number of things that can be carried out so that future learning is more effective [9], namely 1) There is clear technical guidance on the implementation of learning at home, 2) Facilities and infrastructure are fulfilled evenly for all schools, 3 ) There is provision for all teachers about online learning, 4) The education office facilitates interesting learning materials to be accessed by educators as a support for online learning materials, 5) There is socialization and cooperation between the government, schools, parents of students and the community about online learning, 6) All schools must be endeavored to have the same facilities in accessing clear applications in online learning. Teachers and students must also be able to optimize technology [7][9].

Online learning in the future is of course still needed even though some respondents also want and suggest that they can return to face-to-face learning [10]. This is because they find it difficult to carry out online learning and feel online learning is not effective. 


\section{Conclusion}

In order to prevent the spread of Covid-19 in the school environment, the government from the central to the regions has implemented a home learning policy. This policy, of course, inevitably has to be followed by all education units in Indonesia. With various circumstances and limitations that exist, the Korwilgam of Pejawaran District, Banjarnegara Regency, Central Java has also implemented this policy. Online learning as an alternative to conventional learning has to be implemented even though not all schools can implement it. Through this research, we can see that in general teachers are able to implement learning and learning policies at home. However, there are several things that we must pay attention to and improve in the future, namely the unsatisfactory level of learning effectiveness, the competence of human resources that still needs to be improved, and the fulfillment of facilities and infrastructure both devices and networks for online learning that must be evenly distributed. Learning during this pandemic has not been effective, but in the future, with the various experiences that have been, hopefully learning can be better prepared, well organized, and effective in achieving its goals.

\section{Acknowledgment}

Thank you forMr. Wakhudin and Korwilcam Pejawaran who have supported this research and also to his beloved teacher friends in Pejawaran, Banjarnegara who have taken the time to fill out the questionnaire in this research.

\section{References}

[1] WHO. (nd). Points of entry and mass gatherings. Retrieved March 28, 2020, from https://www.who.int/emergencies/diseases/novel-coronavirus-

2019/technicalguidance/points-of-entry-and-mass-gatheringsAsrori.Muhammad. (2012). Psychology of Learning. Bandung: CV Wacana Prima, 6.

[2] Ministry of National Education. (2006). Regulation of the Minister of National Education Number 22 of 2006. Jakarta: Depdiknas

[3] Husamah H. Blended project based learning: thinking skills of new students of biology education department (environmental sustainability perspective). Jurnal Pendidikan IPA Indonesia. 2015 Nov 2;4(2).

[4] Pujilestari Y. Dampak positif pembelajaran online dalam sistem pendidikan Indonesia pasca pandemi covid-19. Adalah. 2020 Apr 19;4(1).

[5] Ponticorvo M, Di Fuccio R, Ferrara F, Rega A, Miglino O. Multisensory educational materials: five senses to learn. InInternational Conference in Methodologies and intelligent Systems for Techhnology Enhanced Learning 2018 Jun 20 (pp. 45-52). Springer, Cham.

[6] Anggoro S, Sopandi W, Sholehuddin M. Influence of joyful learning on elementary school students' attitudes toward science. In Journal of Physics: Conference Series 2017 Feb 1 (Vol. 812, No. 1, p. 012001). IOP Publishing.

[7] Moore JL, Dickson-Deane C, Galyen K. e-Learning, online learning, and distance learning environments: Are they the same?. The Internet and higher education. 2011 Mar 1;14(2):12935.

[8] Firman F, Rahayu S. Pembelajaran online di tengah pandemi covid-19. Indonesian Journal of 
Educational Science (IJES). 2020 Apr 27;2(2):81-9.

[9] Chauhan S. A meta-analysis of the impact of technology on learning effectiveness of elementary students. Computers \& Education. 2017 Feb 1;105:14-30.

[10] Khasanah DR, Pramudibyanto H, Widuroyekti B. Pendidikan dalam masa pandemi covid-19. Jurnal Sinestesia. 2020 Apr 23;10(1):41-8. 